\title{
Acyl Chlorides as Dual Source of Carbon Nucleophile and Carbon Monoxide
}

\section{Key words}

palladium catalysis

carboformylation

hydroformylation

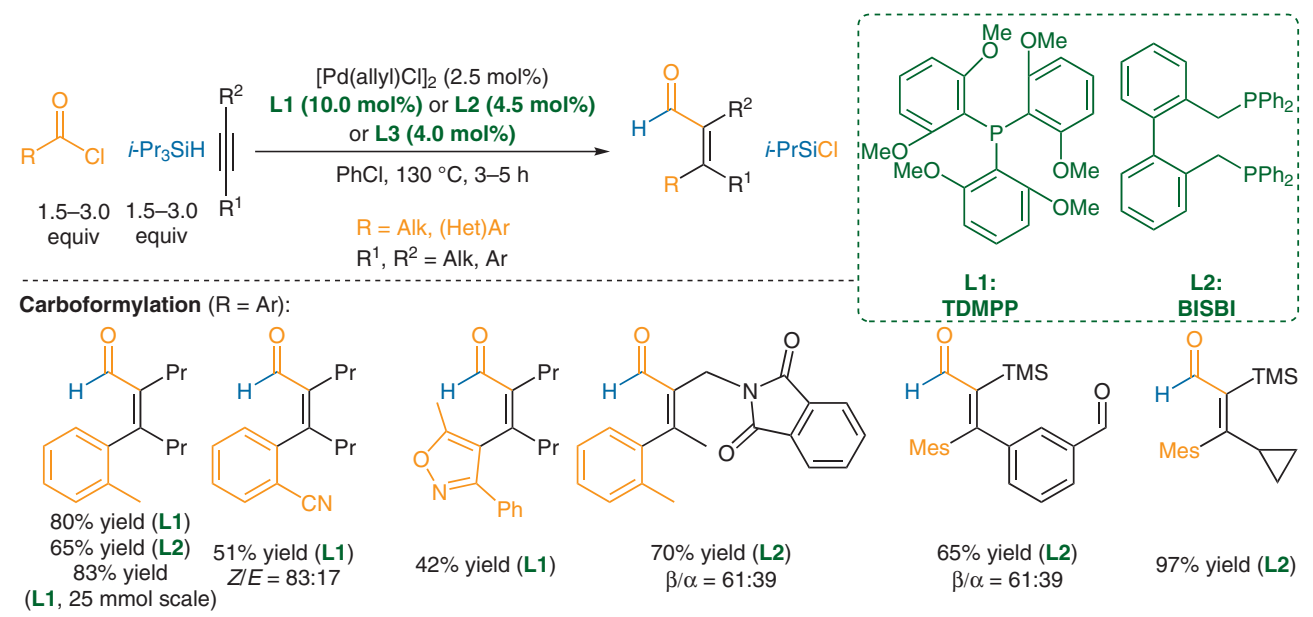

\section{Synfact 13 \\ of the Month}

Hydroacylation $\left(\mathrm{R}=\mathrm{Alk}, \mathrm{Bu}_{3} \mathrm{SnR}\right.$ instead of $\left.i-\mathrm{Pr}_{3} \mathrm{SiH}\right)$ :<smiles>O=C(C=CCBr)C(Br)=Cc1ccccc1</smiles><smiles>C=CCC(=O)C(Br)=CBr</smiles><smiles>C/C(=C/C(=O)c1ccccc1)C[Pb]</smiles><smiles>O=C(/C=C\C(=O)c1ccccc1)c1ccccc1</smiles>

$61 \%$ yield, L3 $43 \%$ yield, L3 $62 \%$ yield, L3
$\beta / \alpha=73.27$ $47 \%$ yield, L3 Hydroformylation $(\mathrm{R}=\mathrm{Alk})$ :<smiles>CC=CC(C)Br</smiles>

$60 \%$ yield, L3<smiles>[2H]C(=O)/C(Br)=C/Br</smiles>

$45 \%$ yield, L3

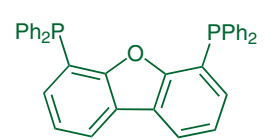

L3:

Carboacylation $\left(\mathrm{R}=\mathrm{Ar}, \mathrm{Bu}_{3} \mathrm{SnR}\right.$ instead of $\left.i-\mathrm{Pr}_{3} \mathrm{SiH}\right)$ :<smiles>CCC(C)=C(C(=O)c1ccccc1)C(C)(C)C</smiles>

$79 \%$ yield, L3<smiles>C=CCC(=O)C(C)C</smiles>

$32 \%$ yield, L3<smiles>O=Cc1ccccc1-c1ccccc1</smiles>

$75 \%$ yield, L3

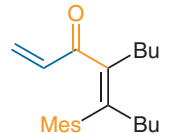

$34 \%$ yield, L3
Significance: The authors report a palladiumcatalyzed carboformylation of alkynes. Acyl chlorides here serve both as CO source and as a carbon nucleophile source. Bulky silane delivers the reducing hydride in a timely manner avoiding premature reduction of palladium intermediates. A catalytic system is comprised of $[\mathrm{Pd}(\text { allyl }) \mathrm{Cl}]_{2}$ and a ligand with an additional hemilabile coordination site (MeO group for TDMPP and second phosphine for BISBI). Interestingly, carbonylation proceeds at high temperature even in an open system.
Comment: Internal alkynes are very good substrates but poor regioselectivities are often observed for unsymmetrical alkynes. Moreover, the reaction is adapted to hydroformylations, hydroacylation and carboacylations with small changes of substrates and ligands. For example, aliphatic acyl chlorides give the hydroformylation and hydroacylation products due to the formation of the $\mathrm{Pd}-\mathrm{H}$ intermediate via $\beta$-hydride elimination. When silyl hydride is replaced with a tributylstanane, the acylation instead of the formylation product is formed. 